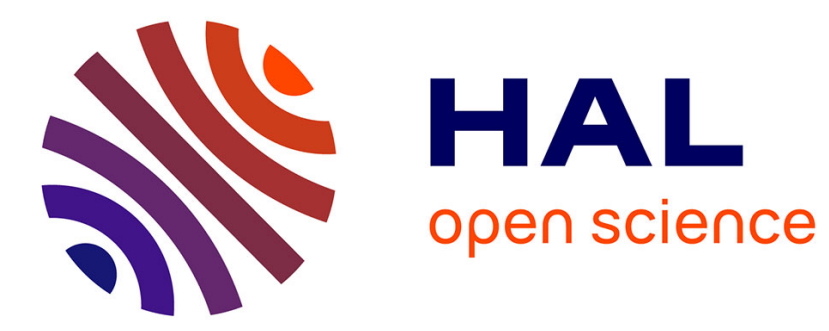

\title{
Second Harmonic Generation imaging of collagen fibrillogenesis
}

S Bancelin, Carole Aimé, Vaïa Machairas, Etienne Decencière, Claire Albert, G Mosser, T. Coradin, Marie-Claire Schanne-Klein

\section{- To cite this version:}

S Bancelin, Carole Aimé, Vaïa Machairas, Etienne Decencière, Claire Albert, et al.. Second Harmonic Generation imaging of collagen fibrillogenesis. Lasers and Electro-Optics Europe (CLEO EUROPE/IQEC), Jun 2013, Munich, Germany. pp.1 - 1, 10.1109/CLEOE-IQEC.2013.6801528 . hal01082882

\section{HAL Id: hal-01082882}

https://hal-mines-paristech.archives-ouvertes.fr/hal-01082882

Submitted on 14 Nov 2014

HAL is a multi-disciplinary open access archive for the deposit and dissemination of scientific research documents, whether they are published or not. The documents may come from teaching and research institutions in France or abroad, or from public or private research centers.
L'archive ouverte pluridisciplinaire HAL, est destinée au dépôt et à la diffusion de documents scientifiques de niveau recherche, publiés ou non, émanant des établissements d'enseignement et de recherche français ou étrangers, des laboratoires publics ou privés. 


\title{
Second Harmonic Generation imaging of collagen fibrillogenesis
}

\author{
S. Bancelin ${ }^{1}$, C. Aimé2 , V. Machairas ${ }^{3}$, E. Decencière ${ }^{3}$, C. Albert ${ }^{2}$, G. Mosser², T. Coradin ${ }^{2}$ and M.-C. \\ Schanne-Klein ${ }^{1}$ \\ 1. Laboratory for Optics and Biosciences, Ecole Polytechnique - CNRS - InsermU696, 91128 Palaiseau, France. \\ 2. Laboratory for Chemistry of Condensed Matter, UPMC - Collège de France - CNRS, 75005 Paris, France. \\ 3. Centre of Mathematical Morphology, Mines ParisTech, 77305 Fontainebleau, France
}

Development of nonlinear optical microscopy has significantly improved three-dimensional (3D) imaging of biological tissues in recent years. In particular, collagen has been shown to exhibit endogenous Second Harmonic Generation (SHG) signals and SHG microscopy has proved to enable the visualization of collagen architecture in tissues with unequalled contrast and specificity [1, 2]. Type I collagen is a major structural protein in mammals and shows highly structured macromolecular organizations specific to each tissue. It is synthesized by cells as triple helices, which self-assemble outside the cells into fibrils that further form fibers, lamellae or other three-dimensional (3D) networks. This assembly mechanism depends critically on the collagen concentration, as well as on the temperature, $\mathrm{pH}$ and ionic strength of the solution in vitro. Thorough characterization of collagen fibrillogenesis is crucial to understand the biological mechanisms of tissue formation and tissue remodeling in response to a variety of pathologies. Booming of tissue engineering furthermore requires advanced in situ quantitative imaging techniques to verify whether the tissue substitutes display appropriate biomimetic 3D organization for cell culture scaffolds or functional implants.

In this study, we continuously monitored the formation of collagen fibrils by time-lapse SHG microscopy [3]. Fibrillogenesis was triggered in a controlled way by increasing the $\mathrm{pH}$ in a dilute solution of collagen I. The fibril density was measured every 10 to 20 minutes as the number of voxels with significant SHG signal in $3 \mathrm{D}$ image stacks [1]. Our results showed reproducible dynamics of fibrillar collagen formation that could be changed by tuning the $\mathrm{pH}$ (see figure 1). We also monitored the growth of single fibrils and measured the length increase over time, which had never been reported before using an optical technique. We then correlated these SHG images to TEM images at nanometer-scale resolution by blocking the fibrillogenesis at early stages and drying the samples. It showed that SHG microscopy allows imaging of fibrils with a diameter down to 30-50 nm in our experimental conditions. We finally investigated surface-mediated fibrillogenesis by adding silica nanoparticles to the solution [4]. We used Two-Photon excited fluorescence (2PEF) microscopy to visualize the fluorescently-died nanoparticles and quantify the self-assembly of collagen around these nanoparticles.

In conclusion, SHG microscopy enabled sensitive and well contrasted 3D visualization of collagen fibrillogenesis in a non invasive way. This work illustrates the potential of SHG microscopy for the rational design and characterization of collagen-based biomaterials.

(a)

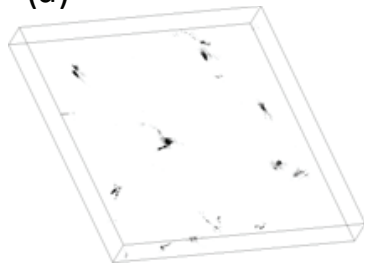

(b)

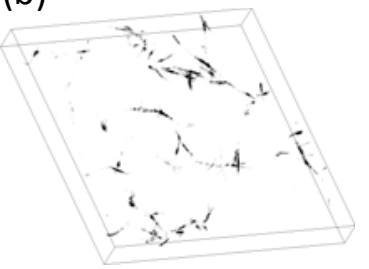

(c)

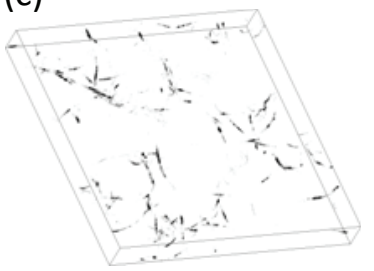

(d)

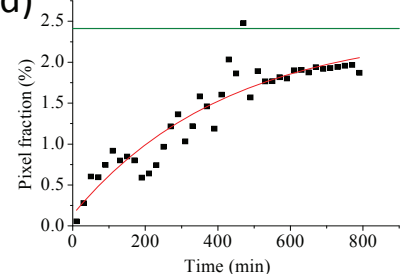

Fig 1. 3D reconstruction of SHG images of collagen fibrillogenesis (at $\mathrm{pH}=6.5$ ) after a) 170 b) 410 and c) 730 minutes; d) Experimental kinetics of fibril density in the SHG images (black dots) with exponential fitting (red line).

\section{References}

[1] M. Strupler, M. Hernest, C. Fligny, J.-L. Martin, P.-L. Tharaux, and M.-C. Schanne-Klein, "Second Harmonic Microscopy to Quantify Renal Interstitial Fibrosis and Arterial Remodeling," J. Biomed. Optics 13, 054041 (2008).

[2] A. Deniset-Besseau, J. Duboisset, E. Benichou, F. Hache, P.-F. Brevet, and M.-C. Schanne-Klein, "Measurement of the second order hyperpolarizability of the collagen triple helix and determination of its physical origin.," J. Phys. Chem. B 113, 13437-13445 (2009).

[3] S. Bancelin, C. Aimé, T. Coradin, and M.-C. Schanne-Klein, "In situ three-dimensional monitoring of collagen fibrillogenesis using SHG microscopy," Biomed. Opt. Express 3, 1446-1454 (2012).

[4] C. Aimé, G. Mosser, G. Pembouong, L. Bouteiller, and C. Thibaud, "Controlling the nano-bio interface to build collagen/silica selfassembled networks," Nanoscale 4, 7127-7134 (2012). 